\title{
Energy shifts meet environmentalist protests
}

\section{Moves to convert power stations from oil to coal are generating controversy about the effects on air quality. David Dickson} reports on one such dispute in New York City.

In a classic trade-off between energy and environmental concerns, New York city last week approved a temporary waiver of its air pollution controls to allow a local power company, Consolidated Edison to burn fuel with a greater sulphur content than is currently permitted.

The company hopes to be able to demonstrate that it is able to use high rather than low sulphur content fuels at its power plants in the city without exceeding federal air pollution standards, and that this will make it possible for the plants to convert from oil to coal, a move supported by President Carter as part of his strategy to reduce dependence on foreign oil.

Local environmental and community groups, however, are protesting against the proposal, which has yet to be given official approval by the federal Environmental Protection Agency. They argue that current controls permitting only the burning of oil with a law sulphur content have been one of the most effective antipollution measures in the city's history and that moving back to higher sulphur content fuels could eliminate some of the gains of the past decade.

Con. Ed. has for several years been trying to get permission to increase the sulphur content of the fuel burnt in its power plants. It claims that not only would conversion to coal be in line with administration policy, but that with escalating oil prices, it would also be financially beneficial to customer companies.

In the previous year, the company's application has been turned down, largely on the grounds that the company has not been able to demonstrate that the current policy results in any particular hardship. Since then, however, the political climate for such decisions has changed dramatically.

In his energy message to Congress in July, for example, President Carter stressed his support for power companies converting from oil to coal. He is expected to submit to Congress soon measures costing even more than the $\$ 5$ billion that he originally proposed to stimulate the use of coal.

A number of utilities have already benefited from the new climate. In Massachusetts, for example, the New England Power Company, after a fouryear battle against stiff local opposition, recently obtained permission to convert three out of four units of a 1,650 megawatt plant from oil to coal, claiming that this would reduce oil consumption in the region by $2.5 \%$.
Last year the company was given permission for an experimental period to burn oil with double the previously permitted $1.1 \%$ sulphur content. Company officials admit that pollution levels increased as a result - but point out that they were still within federallypermitted levels.

The current application form Con. Ed.would allow the company to increase the sulphur content of its fuel from $0.3 \%$ to $1.5 \%$. It claims that converting three power plants from oil to coal would reduce the nation's dependence on oil by 15 million barrels a year - and would also reduce its customer's bills by 150 million.

"The reason for requesting temporary permission to burn high sulphur content oil is to demonstrate the validity of our contention that such a move will not violate federal primary air quality standards", a spokesman for the company said last week.

Permission for a temporary waiver from current controls has already been given by the New York State Department of Environmental Conservation, and by the New York State Department of Environmental Protection. The application will soon be published for public comment by the EPA, and a final decision is expected by next March or April.

Con. Ed.'s application is being strongly resisted by environmental and community groups in New York. "The City's current requirements that only clean fuels - that is low sulphur content oil and natural gas can be used has been one of the most successful pollution control strategies that the city has had, and the sulphur content in the air has dropped by $40 \%$ since the controls were introduced in 1972', says Marcy Benstock, Director of the New York Clean Air Campaign.

Ms Benstock claims that a comparable reduction in dependence on foreign oil could be achieved through an intensive energy conservation programme. She quotes evidence from a report by researchers at Harvard University that the US could consume $30 \%$ to $40 \%$ less energy than at present and still enjoy the same standard of living.

Furthermore, she claims, the apparent reduction in costs could be eaten away by additional medical bills and other damage caused by increasing pollutant levels. Even pollution control devices, she argues, will not be able to remove all the additional pollutants caused by converting to coal, such as some of the toxic trace elements.

A new "wrinkle" as one EPA official puts it, recently to have entered the debate, is concern over the extent to which

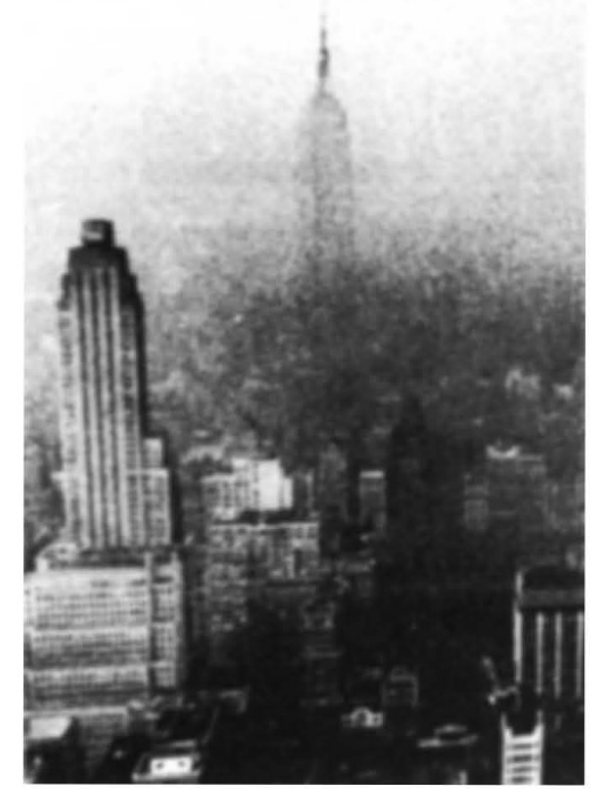

Smog in New York city: will Carter's energy policy make it worse?

increased sulphur emissions could contribute to a problem receiving growing attention in the US, namely acid rain.

According to a spokesman for Con. Ed., the company does not consider this to be too much of a problem since "'by and large the sulphur emissions go out to sea". Others, however, argue that not enough is yet known about transportation patterns to judge the potential degree of the problem.

"At present the burden tends to be on society to show that such things are harmful. But the alternative is equally rational, namely that increased emissions should not be allowed until it can be clearly shown that they are not harmful", says Dr Ellis B Cowling, a plant pathologist from North Carolina State University who has studied the acid rain problem, and gave evidence at an earlier hearing on Con. Ed.'s request.

The transport of pollutants is one of the subjects to be examined in a regional study of metropolitan New York and the adjacent areas of New Jersey and Connecticut that has just been announced by the National Commission on Air Quality.

The company's application to use higher sulphur content fuels is being opposed not only by local groups such as the New York statewide Senior Action Council, and People Outraged With Energy Rates (POWER), but also national groups such as the Sierra Club and the Natural Resources Defense Council.

So far, however, their protests have made little impact, and with the current crisis in Iran bolstering programmes for domestic energy prodution, as well as an administration keen to help power companies comply with federal legislation in the least burdensome way - and a relative lack of financial and human resources compared to those seeking the application - their chances of stopping Con. Ed.'s plans seems increasingly slim. $\square$ 